\title{
KAJIAN DAYA DUKUNG PONDASI TIANG PANCANG PADA STORAGE TANK
}

\author{
Aidil Abrar \\ Program Studi Teknik Sipil Sekolah Tinggi Teknologi Dumai \\ Jl. Utama Karya Bukit Batrem II \\ Email: aidil.abrarce@gmail.com
}

\begin{abstract}
ABSTRAK
Proyek pembangunan pondasi storage tank ini menggunakan pondasi tiang pancang yang berbentuk bulat dengan diameter $40 \mathrm{~cm}$ dan panjang 12 m.Kajian analisis ini untuk menghitung daya dukung tiang pancang dari hasil sondir, standar penetrasi test (SPT) dan membandingkan hasil daya dukung tiang pancang dengan teori klasik ( Mayerhof dan Vesic) serta mengetahui penurunan yang terjadi. Hasil perhitungan daya dukung pondasi terdapat perbedaan nilai, namun yang paling mendekati adalah daya dukung ijin pondasi tiang tunggal dengan menggunakan data sondir dan metode vesic yaitu 168.3 ton/3tiang dan 160.96 ton/3tiang. Untuk perkiraan penurunan yang terjadi berdasarkan penurunan tiang tunggal adalah 9.4 $\mathrm{mm}$ dan tiang kelompok sebesar $9 \mathrm{~mm}$ dengan menggunakan data sondir dan $35.5 \mathrm{~mm}$ dengan menggunakan data SPT, dari hasil penurunan tersebut, maka penurunan total tiang tunggal dan grup memenuhi syarat-syarat yang di ijinkan yaitu $\leq 40 \mathrm{~mm}$.
\end{abstract}

Kata kunci: Storage tank, tiang pancang, penurunan

\begin{abstract}
The construction project of this storage tank uses a round pile foundation with a $40 \mathrm{~cm}$ diameter and $12 \mathrm{~m}$ length. The analysis is to calculate the carrying capacity of the pile of sondir, calculate standard of penetration test (SPT) and compare the carrying capacity of the pile with the theory classic (Mayerhof and Vesic) and know the decline that occurred. Result of calculation of foundation bearing capacity there are difference of value, but the most approximant is carrying capacity of single pole foundation by using data of sondir and vesic method that is 168.3 ton / 3tiang and 160.96 ton / 3tiang. For estimates of the decline that occurred on the basis of a single pole decline is $9.4 \mathrm{~mm}$ and the group pole of $9 \mathrm{~mm}$ using sondir data and $35.5 \mathrm{~mm}$ using SPT data, from the result of the decline, then the total decline of single pole and group meets the permissible conditions ie $\leq 40 \mathrm{~mm}$.
\end{abstract}

Keywords: Storage tank, pile, decline.

UNITEK. Vol. 10 No. 2 Juli - Desember 2017 | p-ISSN 2089-3957 | e-ISSN 2580-2585 


\section{Pendahuluan}

Pada saat ini perkembangan negara Indonesia mengalami kemajuan yang pesat, contohnya dibidang perindustrian. Negara dengan hasil perkebunan yang melimpah ruah, salah satunya adalah perkebunan kelapa sawit yang dalam dasawarsa terakhir ini pengembangan dan perluasan perkebunan kelapa sawit sangat pesat dilakukan di beberapa daerah di Indonesia antara lain: Sumatra, Aceh, Kalimantan, Sulawesi bahkan sampai Papua.

Kelapa sawit tersebut menghasilkan minyak kelapa sawit yang langsung diolah di daerah penghasil. Minyak sawit sering di konsumsi oleh masyarakat untuk minyak goreng, selain itu, minyak kelapa sawit dapat diolah lebih lanjut menjadi asam lemak dan gliserol sebagai bahan dasar (bahan baku) bagi industri oleochemical. Penggunaan terbesar daripada asam lemak adalah dengan mengubahnya menjadi alkohol asam lemak, amida, garam asam lemak dan juga plastik termasuk nilon (hampir mencapai $40 \%$ dari total penggunaannya). Penggunaan terbesar berikutnya sebesar 30\% untuk dijadikan sabun, deterjen, dan kosmetik. Asam lemak juga digunakan sebagai bahan dasar pembuatan resin dan cat sekitar $15 \%$, sisanya digunakan sebagai pembantu dalam industri pembuatan ban, tekstil, kulit kertas, pelumas, lilin. Penggunaan terbesar dari gliserol adalah industri farmasi dan kosmetika serta makanan (Richtler dan Knault, 1984).

Pada pembangunan Oleochemical Plant PT. WINA OLEO ini, ada beberapa bangunan yang didirikan sebagai pendukung pengolahan bahan baku industri tersebut, antara lain didirikan nya building, clarifier, timbangan, storage tank dengan berbagai jenis dan kapasitas yang berbedabeda dan lain-lain. Dalam pelaksanaan tugas akhir ini, penulis hanya akan membahas mengenai pondasi tangki timbun (storage tank) stainless stell kapasitas $4100 \mathrm{~m}^{3}$.

Setelah memperhatikan alasan-alasan tertentu seperti karakteristik tanah, beban struktur atas, lingkungan sekitar proyek maka pada pembangunan Oleochemical Plant ini khususnya tangki stainless stell kapasitas $4100 \mathrm{~m}^{3}$ menggunakan pondasi tiang pancang. Pembuatan pondasi tiang pancang di lakukan di pabrik, kemudian di bawa kelokasi proyek. Pondasi tiang pancang terdiri dari beberapa tiang dalam satu kelompok (grup) tiang yang di satukan dengan menggunakan pile cap. Pile cap ini berfungsi untuk mendistribusikan beban keseluruh tiang. Untuk penyelidikan geoteknik yang dilakukan adalah penyelidikan lapangan (In situ test) yang terdiri dari sondir (Cone Penetrasi Test/CPT) dan Standart Penetrasi Test (SPT). Pengujian sondir dilakukan sebanyak 20 titik, dengan menggunakan sondir kapasitas 2.5 ton dan kecepatan pemutaran $1 \mathrm{~cm} /$ detik 
dengan kedalaman $27.80 \mathrm{~m}$ dan SPT sebanyak 5 titik pengujian dengan kedalaman 45 meter.

Tujuan dari kajian ini adalah menganalisa dan membandingkan kapasitas daya dukung pondasi spun pile group pada tangki stainless stell kapasitas $4.100 \mathrm{~m}^{3}$ dari data lapangan (Sondir dan Standard Penetrasi Test dengan teori klasik ,Meyerhof dan Vesic ) dan Menghitung penurunan yang terjadi pada tiang pancang spun pile.

\section{Metode Penelitian}

Metode Analisis yang dipakai untuk menentukan tujuan kajian dari penururnan tiang grup ini.

\section{Kapasitas Daya Dukung Tiang}

Dalam menentukan kapasitas dukung tiang diperlukan klasifikasi tiang dalam mendukung beban yang bekerja. Menurut Terzaghi, klasifikasi tiang didasarkan pada pondasi tiang yaitu :

1. Tiang gesek (friction pile), bila tiang pancang pada tanah berbutir. Akibat pemancangan tiang, tanah disekitar tiang menjadi padat. Porositas dan kompresibilitas tanah akibat getaran pada waktu tiang dipancang menjadi berkurang dan angka gesekan antara butir - butir tanah dan permukaan tiang pada arah lateral menjadi bertambah.

2. Tiang lekat (cohesion pile), bila tiang dipancang pada tanah lunak (permeabilitas rendah) atau tanah mempunyai kohesi yang tinggi.

3. Tiang mendukung dibagian ujung tiang (point / end bearing pile), bila tiang dipancang dengan ujung tiang mencapai tanah keras sehingga seluruh beban yang dipikul oleh tiang diteruskan ke tanah keras melalui ujung tiang.

4. Tiang tekan, bila tiang telah menumpu pada tanah keras dan mendapatkan tekanan vertikal dari beban mati maupun beban hidup.

5. Tiang tarik, bila tiang pancang pada tanah berbutir mendapat gaya yang bekerja dari lendutan momen yang mengakibatkan tiang mengalami gaya tarik.

6. Pada kenyataannya di lapangan, tanah sangat heterogen dan pada umumnya merupakan kombinasi dari kelima hal tersebut di atas. Berbagai metode dalam usaha menentukan kapasitas dukung tiang ini, tapi umumnya dibedakan dalam dua kategori yaitu untuk tiang tunggal dan kelompok tiang.

Untuk kelancaran Kajian analisi maka diperlukan beberapa data yang digunakan sebagai sarana untuk mencapai maksud dan tujuan penelitian. Data yang diperlukan antara lain :

- gambar detail bangunan storage tank stainless steel kapasitas $4100 \mathrm{~m}^{3}$ seperti gambar struktur bangunan storage tank stainless stell kapasitas $4100 \mathrm{~m}^{3}$ antara lainmeliputi : Profil baja yang di pakai untuk rafter dan girder pada

UNITEK. Vol. 10 No. 2 Juli - Desember 2017 | p-ISSN 2089-3957 | e-ISSN 2580-2585 
roof tangki, ukuran plate shell stainless steel, plate stainless steel untuk roof dan bottom plate, detail pondasi dan bitumen.

- hasil uji penyelidikan tanah ( data sondir dan data standard penetrasi test ) Pada pembangunan storage tank ini, penyelidikan tanah yang dilakukan adalah penyelidikan lapangan yang terdiri dari Standart Penetration Test (SPT) dan sondir. Dari hasil penyelidikan tanah tersebut dapat di baca dimana kedalaman tanah kerasnya, jenis tanah pada lapisan dan kedalaman nya yang akan digunakan untuk mendesain pondasi. Pada pengujian Standar Penetration Test dilakukan sebanyak 5 titik pengujian dan dari data sondir dilakukan sebanyak 20 titik pengujian.

- Dimensi atau ukuran tiang pancang yang dipakai adalah diameter $40 \mathrm{~cm}$ yang berbentuk bulat ( spun pile) dengan mutu beton K-500. Sedangkan panjang pondasi tiang pancang tersebut sekitar 35 meter yang di dasar kan pada kedalaman tanah keras dari penyelidikan tanah SPT.Tiang pancang dibenamkan kedalam tanah sebanyak 3 tiang dengan panjang 1 tiang adalah 12 meter.

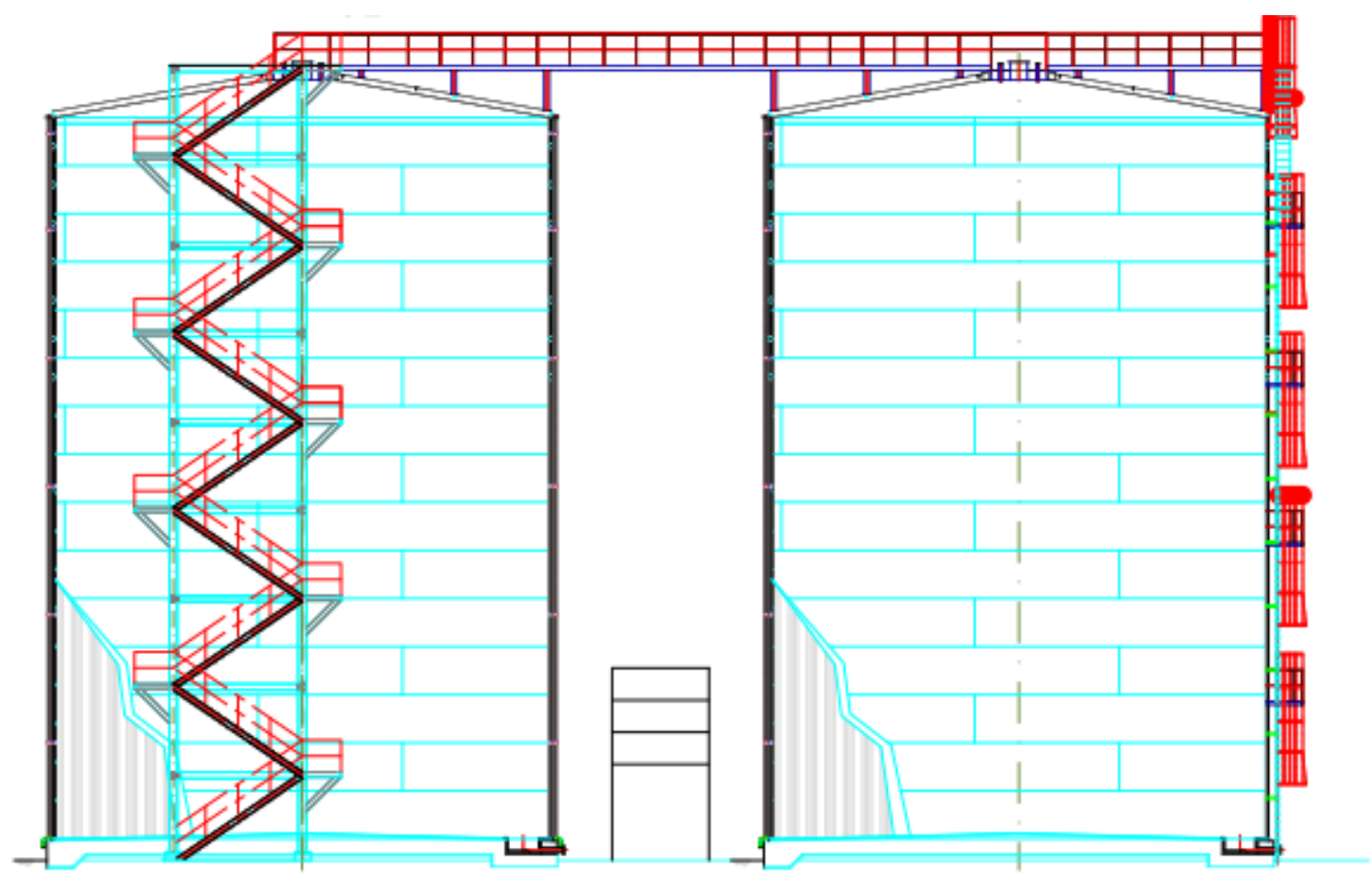

Gambar 1. Permodelan Tanki 


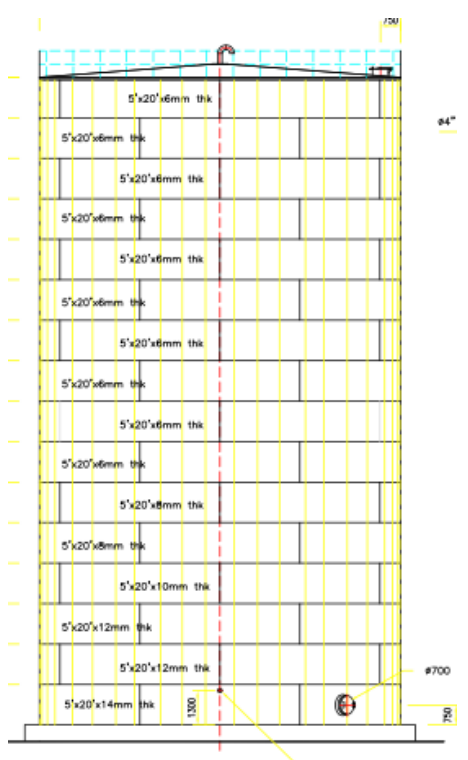

(a)
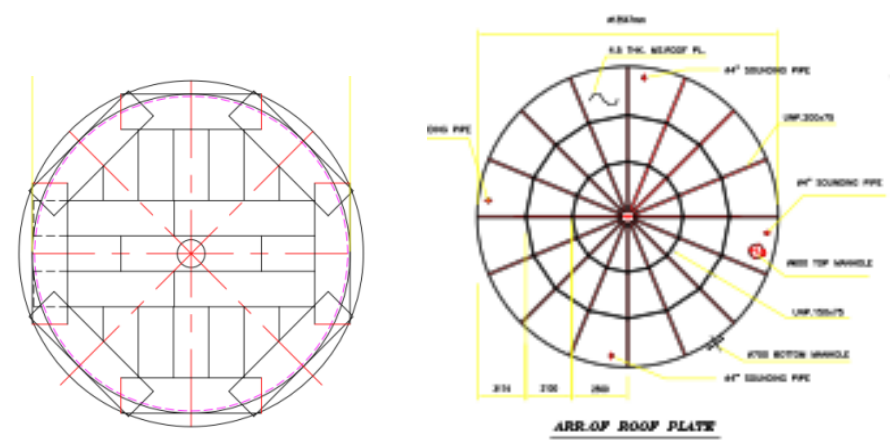

(b)

(c)

Gambar 2. Storage tank (a) Tampak Tangki, (b) Pondasi Tanki, (c) Atap/Roof Tanki

\section{Analisis Pondasi Tiang Pancang}

Dalam menganalisis pondasi tiang pancang, beban yang bekerja pada kolom harus diketahui terlebih dahulu. Setelah kapasitas daya dukung kelompok tiang didapat, maka perlu dihitung juga efisiensi kelompok tiang tersebut.

\section{Analisis Penurunan Pondasi Tiang Pancang}

Besarnya penurunan tergantung pada karakteristik tanah dan penyebaran tekanan pondasi ketanah dibawahnya.Penurunan pondasi tiang dihitung berdasarkan tiang tunggal dan tiang kelompok. 

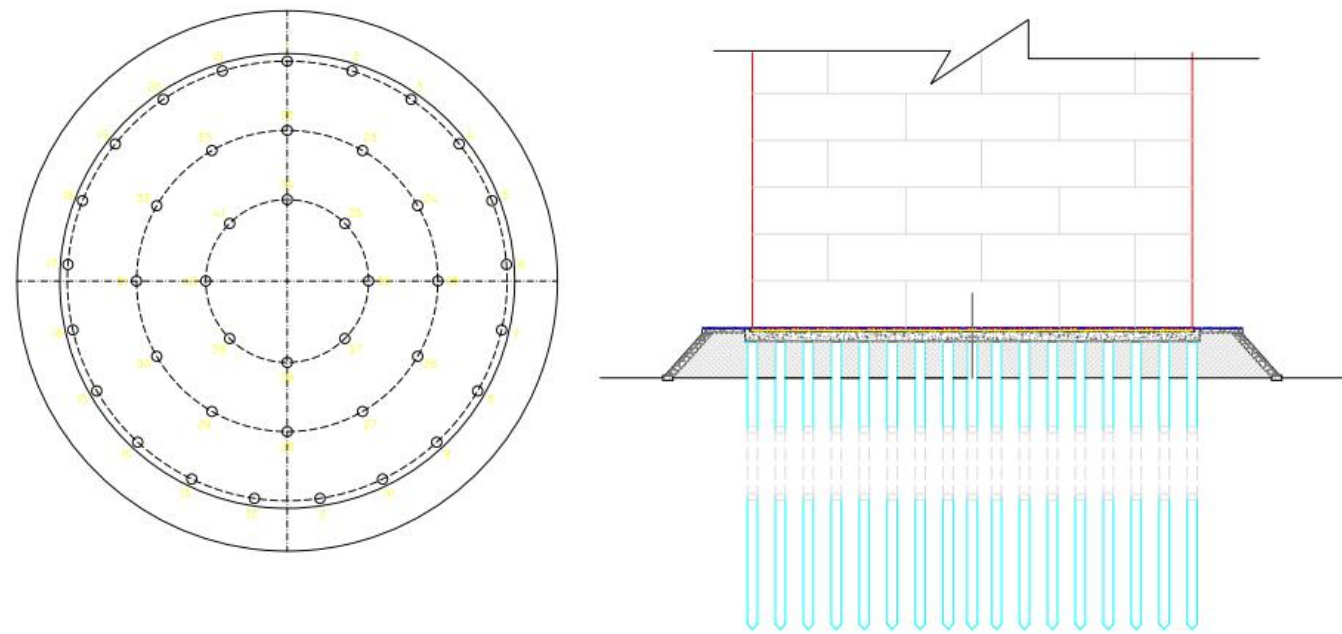

Gambar 3. Pondasi Tiang pancang

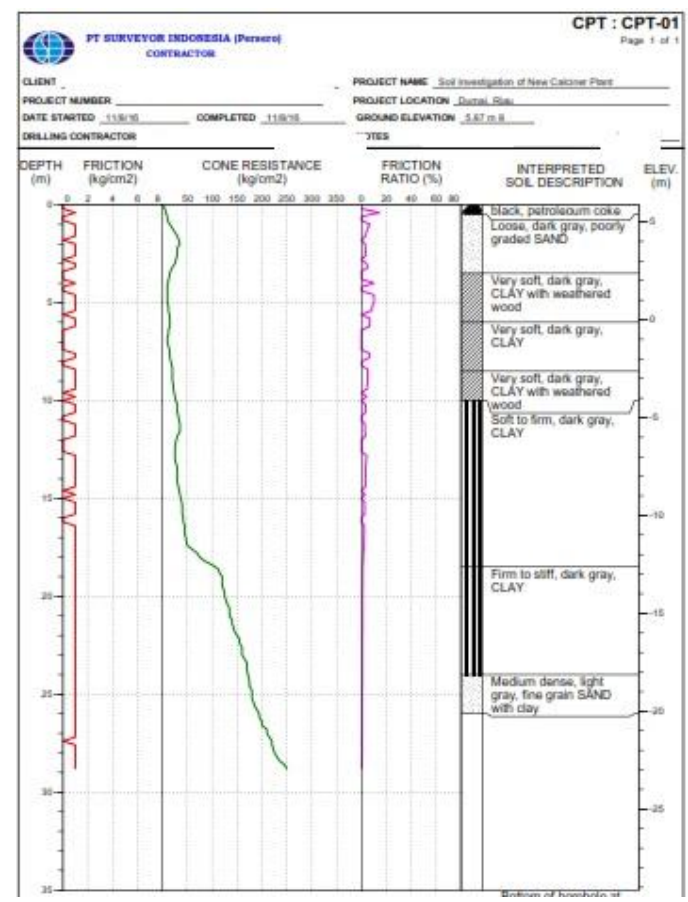

Gambar 4. Contoh hasil pengujian SPT tanah

\section{Hasil dan Pembahasan}

\section{Analisa Daya Dukung Tiang Berdasarkan Data Lapangan}

Pengujian lapangan yang representatif untuk digunakan sebagai data masukkan untuk analisis daya dukung pondasi tiang adalah pengujian data sondir (qc) dan pengujian tumbukan standard (Nspt). Metoda yang dikembangkan untuk kedua jenis pengujian lapangan tersebut sangat 
tergantung pada peneliti yang mengusulkan.Metode analisis berdasarkan data pengujian sondir umumnya dikembangkan dengan memperhatikan factor keamanan yang cukup. Sedangkan data pengujian standard, digunakan sebagai nilai koreksi ataupun tidak yang kemudian dimasukkan dalam persamaan empiris ( tidak langsung ).(Hakam. A ).

a. Daya Dukung Tiang Berdasarkan Data Sondir

$$
\mathrm{Qa}=\frac{Q c \cdot A b}{3}+\frac{F s_{A S}}{2}
$$

dimana :

Qa = Daya dukung ijin tiang $(\mathrm{kg})$

Qc $\quad=$ Cone Resistant $\left(\mathrm{kg} / \mathrm{cm}^{2}\right)$

Fs $\quad=$ Friction Skin $\left(\mathrm{kg} / \mathrm{cm}^{2}\right)$

$\mathrm{Ab} \quad=$ Luas dasar tiang $\left(\mathrm{cm}^{2}\right)$

As $\quad=$ Luas selimut tiang $\left(\mathrm{cm}^{2}\right)$

3 dan 2 = Faktor keamanan

\section{b. Daya Dukung Tiang Berdasarkan Data SPT}

$$
\mathrm{Qb}=4 \mathrm{Nb} * \mathrm{Ap}
$$

dan

$$
\text { Qs } \quad=1 / 50 * \mathrm{Nr} * \mathrm{As}
$$

dimana,

$\mathrm{Ap}=$ luas penampang

$\mathrm{Nb}=$ Nilai N-SPT pada elevasi dasar tiang

$\mathrm{Nr}=$ Nilai Nspt rata-rata

As = luas selimut tiang

Untuk daya dukung ijin menggunakan data Nspt adalah sebagai berikut :

$$
\mathrm{Qa}=\frac{Q p+Q s}{3}
$$

dimana,

3 = Faktor keamanan

\section{Analisa Daya Dukung Tiang Berdasarkan Teori Klasik}

Kapasitas daya dukung dari teori-teori klasik memang sangat menarik untuk dibahas mendalam. Walaupun teori ini dibuat berpuluh tahun yang lalu, dengan berdasarkan pada percobaan sederhana dan menggunakan parameter taanh yang ala kadarnya ( hanya menggunakan parameter tanah $\mathrm{Y}$, c dan $\theta$ ) namun telah banyak diterapkan dalam pekerjaan praktis yang tidak mengecewakan hasilnya. 
Toeri - teori klassik yang sering di gunakan adalah metode Mayerhof, metode Vesic, metode Janbu dan metode Terzaghi.Namun dalam penelitian ini metode klassik yang digunakan adalah metode Mayerhof dan metode Vesic karena kedua metode ini hasil daya dukung nya mendekati dengan data lapangan.

\section{Resume Hasil Perhitungan Daya Dukung Ijin Tiang}

Tabel 1.Daya dukung ijin tiang pancang tunggal

\begin{tabular}{|c|l|c|}
\hline No & \multicolumn{1}{|c|}{ Metode dan perhitungan } & $\begin{array}{c}\text { Daya dukung ijin tiang } \\
\text { pancang } \\
(\text { ton })\end{array}$ \\
\hline 1 & Berdasarkan data sondir maksimum & $56.1 * 3=168.3$ \\
\hline 2 & Berdasarkan data SPT maksimum & $48.27 * 3=144.81$ \\
\hline 3 & Berdasarkan material tiang pancang & $114.88^{*} 3=434.64$ \\
\hline 4 & Metode mayerhof & 192.92 \\
\hline 5 & Metode Vesic & 160.96 \\
\hline & $\begin{array}{l}\text { Berdasarkan daya dukung sisi metode } \\
6\end{array}$ & klasik \\
\hline
\end{tabular}

Sumber : perhitungan

Pada tabel 1 dapat kita lihat bahwa daya dukung tiang berdasarkan data lapangan dan menggunakan metode klasik memiliki hasil perhitungan yang berbeda-beda. Untuk daya dukung tiang tunggal berdasarkan data lapangan menggunakan safety factor 2.5 sedangkan untuk daya dukung tunggal berdasarkan metode klasikmenggunakan safety factor 3. Namun perbedaan yang paling mendekati antara daya dukung tiang berdasarkan data lapangan dengan metode klasik adalah berdasarkan data sondir dengan metode vesic.

Tabel 2.Perhitungan daya dukung ijin tiang grup

\begin{tabular}{|c|l|c|}
\hline No & \multicolumn{1}{|c|}{ Metode dan Perhitunga } & $\begin{array}{c}\text { Daya dukung ijin } \\
\text { tiang pancang } \\
\text { (ton })\end{array}$ \\
\hline 1 & Berdasarkan data sondir & 7546.57 \\
\hline 2 & Berdasarkan data SPT & 6493.28 \\
\hline 3 & Berdasarkan material tiang pancang & 19489.26 \\
\hline 4 & Metode mayerhof & 8650.53 \\
\hline 5 & Metode Vesic & 7201.3 \\
\hline 6 & Berdasarkan daya dukung sisi metode klasik & 8557.27 \\
\hline
\end{tabular}

Sumber : perhitungan 
Pada daya dukung tiang grup safety factor yang digunakan adalah 3 dengan nilai effisiensi grup tiang nya adalah $76 \%$. Nilai effisiensi grup tiang ini menunjukkan perbandingan antara kapasitas daya dukung grup tiang dengan penjumlahan seluruh kapasitas daya dukung tiang-tiang tunggal.

\section{Analisa Perkiraan Penurunan Tiang}

Penurunan yang di izinkan dari suatu bangunan bergantung pada beberapa faktor.Faktor-faktor tersebut meliputi jenis, tinggi, kekakuan, dan fungsi bangunan, serta besardan kecepatan penurunan serta distribusinya.Karena penurunan maksimum dapat diprediksi dengan ketetapan yang memadai, umumnya dapat diadakan hubungan antara penurunan yang diizinkan dengan penurunan maksimum. Dimana syarat perbandingan penurunan yang aman yaitu :

$$
\begin{aligned}
\text { Stotal } & \leq \text { Sizin } \\
\text { Sizin } & =10 \% \text { diameter tiang } \\
& =10 \% * 40 \mathrm{~cm} \\
& =4 \mathrm{~cm}
\end{aligned}
$$

Tabel 3. Perkiraan penurunan tiang tunggal

\begin{tabular}{|c|c|c|}
\hline No & Bentuk penurunan & Penurunan Tiang ( S ) \\
\hline 1 & Untuk tiang apung atau friksi & $5.4 \mathrm{~mm}$ \\
\hline 2 & Untuk tiang dukung ujung & $4 \mathrm{~mm}$ \\
\hline 3 & Total Penurunan & $9.4 \mathrm{~mm}$ \\
\hline
\end{tabular}

Sumber : Perhitungan

Pada tabel 3 Untuk penurunan tiang tunggal, diperhitungkan dengan dua cara, yaitu dengan cara penurunan tiang dukung apung/friksi dan penurunan tiang dukung ujung. Untuk penurunan tiang dukung friksi didapat kan hasil $5.4 \mathrm{~mm}<40 \mathrm{~mm}$, berarti penurunan tidak melebihi batas yang diizinkan (aman), untuk penurunan tiang dukung ujung didapatkan hasil $4 \mathrm{~mm}<40 \mathrm{~mm}$, berarti penurunan tidak melebihi batas yang di izinkan (aman).

Untuk perhitungan penurunan tiang kelompok dilakukan dengan metode mayerhof. Berdasarkan metode mayerhof, penurunan dihitung dengan menggunakan data lapangan yaitu dengan data sondir dan data SPT. Untuk data sondir di dapatkan hasil penurunan sebesar $9 \mathrm{~mm}<40 \mathrm{~mm}$, berarti penurunan dalam batas yang di izinkan ( aman ), berdasarkan data SPT di dapat hasil penurunan tiang grup sebesar $35.5 \mathrm{~mm}<40 \mathrm{~mm}$, berarti penurunan dalam batas yang di izinkan (aman).

\section{Simpulan}

UNITEK. Vol. 10 No. 2 Juli - Desember 2017 | p-ISSN 2089-3957 | e-ISSN 2580-2585 
Dari analisis yang telah dilakukan, dapat diambil kesimpulan sebagai berikut ini :

a. Berdasarkan analisa pembebanan, pondasi storage tank kapasitas 4100 $\mathrm{m}^{3}$ dalam keadaan aman, karena beban luar yang bekerja lebih kecil dibandingkan dengan kapasitas daya dukung ijin tiang kelompok dan dari perbandingan kapasitas daya dukung ijin tiang, hasil teori klasik ( metode Vesic ) lebih mendekati dengan hasil pengujian di lapangan ( data sondir ).

b. Pondasi storage tank stainless steel kapasitas $4100 \mathrm{~m}^{3}$ aman terhadap penurunan, karena berdasarkan hasil perhitungan perkiraan penurunan tiang tunggal dan kelompok tidak melebihi batas-batas penurunan yang di ijinkan.

\section{DaftarPustaka}

Bowles, J, E.,1991, Analisa dan Desain Pondasi, Edisi keempat jilid 1, Erlangga, Jakarta.

Bowles,J, E., 1993, Analisa dan Desain Pondas, Edisi keempat jilid 2, Erlangga, Jakarta.

Hakam, A, Darjanto., 2008, Rekayasa Pondasi, Bahan Kuliah Fakultas Teknik Sipil.

API 620 -Design and Construction of Large, Welded, Low Pressure Storage Tanks.

Hardiyatmo, H, C., 1996,Teknik Pondasi 1 , PT Gramedia Pustaka Utama, Jakarta.

Hardiyatmo, H, C., 2002, Teknik Pondasi 2 , Edisi kedua, Beta Offset, Yogyakarta.

Poulos,H.G. \& Davis, E.H.1974, Pile foundation analysis and design, series in geotechnical engineering 